\title{
The Impact of Using Representation Modes within Writing to Learn Activities on the Scientific Process Skills of the Fifth Grade Students
}

\author{
Esra Kabataş Memiş ${ }^{1}$, Muhittin Öz ${ }^{1}$ \\ ${ }^{1}$ Department of Science Education, Kastamonu University, Kastamonu, Turkey \\ Correspondence: Esra Kabataş Memiş, Department of Science Education, Kastamonu University, Kastamonu, Turkey.
}

Received: November 22, 2016

Accepted: December 17, 2016

Online Published: December 21, 2016

doi:10.11114/jets.v5i2.2001

URL: http://dx.doi.org/10.11114/jets.v5i2.2001

\begin{abstract}
The purpose of this research is to determine the impact of using multimodal representation modes in the writing practices done by the fifth grade students on their scientific process skills. A combined research method which had both quantitative and qualitative characteristics was used in the research and the groups were chosen as control and experimental groups. $325^{\text {th }}$ grade students at an elementary school in the North of Turkey formed the study group. Scientific Process Skills Test and writing activities for learning were used as data collection tools in the study. When the unit was completed, the students were asked to tell their peers about the subjects in the unit with a writing activity in the summary writing type. While the students in the experimental group were obliged to use the representation modes in these writing to learn activities, the students in the control group were asked only to complete the writing activity. In this process, the students performed three writing activities, one preparation and two real practice activities. The criteria determining the content and the features of these writing activities (purpose, subject, interlocutor, writing type and page limit) were standards explained in the instructions distributed to the students. The most basic discrepancy between the groups was the request of using of multimodal representations for the students in the experimental group. The writing activities performed within the scope of the study were scored after they were evaluated in consideration of the criteria determined by the researchers. The Cronbach's alpha credibility coefficent of the scientific process skill test applied as the preliminary test in the beginning of the practice and the post-test at the end of it was determined as 72 . The results of the research indicate that using multimodal representations make statistically significant differences on behalf of the experimental group in the scientific process skills of the students.
\end{abstract}

Keywords: writing to learn, multimodal representations, scientific process skill, fifth grade

\section{Introduction}

When the curriculums of the Science lesson are studied, it is seen that the concept of scientific literacy become prominent. The concept of scientific literacy is a concept related to reading and writing, two of the four basic dimensions of language. Students do studies aimed at reading and writing at schools. In these studies, students comprehend the texts, make comments, analyse different situations and make criticizations about these situations. As a result of this situation, scientifically literate individuals think about the possible results of the developments in science and technology and they are interested in the nature of science and scientific research (DeBoer, 2000). This interest directs the individuals to communicate. Correct and influential communication skill an individual has depends on his success in his writing skills which constitute another aspect of communication as well as his speaking skills (Tağa \& Ünlü, 2013). It is known that students can improve their writing skills with writing practices (Glynn \& Muth, 1994; Hand \& Prain, 2002). Writing practices can be used for learning at schools (Klein, 2000; Hand, Lawrence \& Yore, 1999). Writing activities done in classrooms are practiced for different purposes and in different ways. These writing activities are generally practices which are described as traditional writing such as summarizing books, taking notes from the blackboard and preparing laboratory reports (Günel, Atila \& Büyükkasap, 2009). Traditionally, writing education has been a process in which the students ask questions about the text and do exercises and write down the important aspects of the subject in consequence of their researches (Galbraith \& Rijlaarsdam, 1999). Students who do writing activities this way may have difficulty in doing research or making explanations with questioning and realizing their thoughts. Writing practices done in classrooms are expected to transform into a process aimed at explaining and discussing which the students understand, rather than taking notes, preparing experiment reports and doing tests with short answers (Yore, 2000). 
How the writing to learn practices can make learning effective is discussed (Prain \& Hand, 1999; Hand, Hohenshell \& Prain, 2004). About this topic, Hand and Prain (1996), propounded a model which could help the teachers in the writing to learn activities in science classes. This model consists of five components; subject of writing, type of writing, purpose of writing, interlocutor of the text written and the production method of the text (Hand \& Prain, 2002). Hand and Prain (1996) remark that these five different elements can be used in many different ways and strong learning can be enabled this way. Using non-traditional writing in science classes is important because it shows how and why the students learn (Hand, Lawrance \& Yore, 1999). Hence, writing to learn has a potential for influencing the research and questioning skills of the students. It is accepted that writing to learn enables deep concepts about any content to be understood and helps metacognitive learning (Sampson \& Walker, 2012). Moreover, it is known that, when the students usethe writing to learn method, it helps them to learn the concepts and make cause and effect relation contained in the scientific articles and it enables them to be successful writers in forming scientific texts (Hand \& Prain, 2002).

Using the writing to learn method in classrooms can be a tool for the students to express their thoughts making different demonstrations (Tolppanen et al., 2013). Representation modes such as pictures, diagrams, charts, graphics, mathermatical expressions and figures can be exemplified for the demostrations expressed as multimodal representations in the literature. Even if different classifications are made for different purposes, the common general opinion about the modes are the categories of their being expressed with different demonstrations of the same concepts and operations representationally (texts, graphics, charts, tables), figuratively (pictorial, metaphorical, analogical), experimentally and mathematically (Waldrip, Prain \& Carolan, 2006; Günel, Atilla \& Büyükkasap, 2009). Using these multimodal representations is to make connections with scientific sources and show the scientific justifications and findings and to determine the knowledge (Waldrip, Prain \& Carolan, 2006).

Using multimodal representations is to describe the same concept again and again in different ways, describing it like the modes containing pictures, diagrams, tables, graphics and mathematical calculations and doing exercises (Prain \& Waldrip, 2006). For example, mathematical expressions can be used or tables and graphics can be used in order to teach the relation between the two different variables connected to each other. Tables and graphics are representations which make the organization of the data easier in order to comment and have a conclusion (Temiz \& Tan, 2009). The reader can get to the idea the writer likes to tell studying the modal representations which show the relation between two variables more easily than its expression in a plain text. When the nature of the modal representations is regarded, it is understood that the representations are used in the presentation and organization of knowledge, in the stage of structuring the scientific knowledge and during the formation of various meanings (Demirbağ \& Günel, 2014). Understanding science is important for the students from the points of using multimodal representations and thus their seeing that they can understand (Tolppanen et al., 2013). Hence, students need to learn scientific concepts (Atila, Günel \& Büyükkasap, 2009) and understand the variety of the modes aimed at processes (Ainsworth, 2006).

The students can evaluate any changes or developments in their ideas about the subjects they learn at schools by writing and at the same time they learn what the scientifiic processes are (Balgopal, Wallace \& Dahlberg, 2012). The scientific process skills include some skills such as observation, guessing, measuring and classification, recording the data, forming hypotheses and determining the variables (MNE, 2013). The scientific process skills are the basic skills which make learning in science easy, bring in research ways and methods, and enable the students to be active, develop their sense of taking responsibility of their own learning and increase the permanence of learning (Çepni, Ayas, Johnson \& Turgut, 1997). While science is being learnt, speaking and writing, mathematics, images like pictures, graphics and diagrams, devices like experiment and measurement tools and activities aimed to practice are needed (Aslan \& Tekin, 2015). Glynn and Muth (1994), remark that the writing activities are related to the scientific process skills and the learning of the students. The impact of using representation modes in writing to learn activities on the $5^{\text {th }}$ grade students' scientific process skills was searched in this study.

\section{Method}

\subsection{Research Model}

Quantitative and qualitative research methods were used in this study. A half experimental research method was used as the quantitative research method. In the half experimental method, while the experimental group joins the experimental study and it is interfered specifically, there is no experimental interference in the control group (Çepni, 2012). From this point of view, the students in the experimental group were asked to do writing to learn activities in which the use of multimodal representation was expected or demanded, aimed at the purpose of the research. Content analysis was made as the qualitative research method in the study. Content analysis is a method which enables the data given to the researchers to be explained in testing the situations about the problem researched (Elo \& Kyngäs, 2008). While content analysis enables determining the knowledge the writer makes and compiles using various sources and establising the preliminary preparations about writing, it can also propound the amount of the data in a research, for example the 
frequency of the use of the words in a text can be determined with this method (Stemler, 2001). In the study, Scientific Process Skills Test (SPST) was used as the pre and post-tests to measure the scientific process skills of the students and the writing to learn activities prepared by the students were evaluated with content analysis and the data was collected.

\subsection{Participating Student-teacher}

The study was made in 2013-2014 School Year in the province of Kastamonu in the North of Turkey, in an elementary school in a village of the province center. While some of the students were coming from the village where the school was located, some of them were brought to the school by transportation from the neighboring districts. The study groups consist of 325 th grade students in two different classes. It can be said that the students are socially and economically similar. The groups were randomly chosen as the control and experimental groups. The researcher who conducted the study is a teacher with 5 years of experience who applied the writing to learn activities in the classroom environment.

\subsection{The Application Process}

SPST was applied to the students as the preliminary test in the beginning, as aimed at the purpose of the study. Writings /articles in Children's Science Magazine of TUBITAK (The Scientifical and Technological Research Council of Turkey) magazine comprising a lot of representations were distributed to the students in both groups (the Experimental and the Control Groups) before the application and the students were asked to read them and express what they understood. Later, discussions about the multimodal representations were made with the students for them to comprehend why and how they used the representations. In the continuation, after the researcher explained the representations to all of the students, he asked them to classify or determine the multimodal representations (texts, pictures, mathematical expressions, graphics, tables, diagrams, lists) and he introduced them the multimodal representations. Thus, awareness about the multimodal representations was provided. The basic reason why this preliminary study was actualized in both classrooms was to limit the influence of the external variable which could affect the study (Büyüköztürk et al., 2013).

Each of the experimental and control groups determined randomly were explained how they would do the writing to learn activities they had to prepare, distributing them instructions prepared by the researcher. As it was remarked in the instructions, while the students in the experimental group were doing unit based writing to learn activities using multimodal representations for their peers, the students in the control group did writing to learn activities for their peers. Moreover, standards like subject, writing type, interlocutor and the number of pages were indicated in the instructions. It is known that the multimodal representations depend on the attention of the learners and they have a potential for providing effective learning in them (Waldrip, Prain \& Carolan, 2006). Because of this reason, the only and basic difference in the homework instructions was that the students in the experimental group were asked to use the multimodal representations in the writing to learn activities, as something different than the students in the control group. A preliminary practice was done in the first unit of the 5th grade Science lesson (The Unit "Let's Solve the Puzzle of Our Body") for the students to cognize the application process. No evaluation was made in this practice. The intention was only to introduce the students the process. Later, the students were asked to do the same writing to learn activities for both units ("propagation of the light \& voice unit (U1)" and "measuring the magnitude of force unit" (U2)). SPST was applied as the post-test after all of the students did the writing to learn activities for both of the practice units in accordance with the instructions. Thus, the application stage of the study was completed.

\subsection{Data Collection Tools and Statistical Analysis}

\subsubsection{Scientific Process Skills Test}

SPST which is a data collection tool and writing to learn activities were used in the study. The scientific process skill test developed by Kurtuluş and Yiğit (2010) was used as SPST. The researchers studied the publications, theses and articles about scientific process skills while they were developing the test and they formed a measurement tool using four different tests (Kurtuluş, 2012). The tests used by the researchers who developed the test are given in Table 1.

Table 1. Test used as SPST developed by the researchers (Kurtuluş \&Yiğit, 2010)

\begin{tabular}{|c|c|c|c|c|}
\hline Author & $\begin{array}{l}\text { Publication } \\
\text { Year }\end{array}$ & Name of Test & Translator & $\begin{array}{l}\text { Reliability } \\
\text { Coefficient }\end{array}$ \\
\hline Tobin\& Capie & 1982 & $\begin{array}{l}\text { Test of Integrated } \text { Process } \\
\text { (TIPS) }\end{array}$ & Arslan, 1995 & 0.73 \\
\hline Smith \&Welliever & 1986 & Science Process Assesments & Başdağ, 2006 & 0.81 \\
\hline Enger \& Yager & 1998 & Test of Integrated Process Skills & Koray et al.,2007 & 0.77 \\
\hline Aydinlı & 2007 & Scientific Process Skills Test & - & 0.72 \\
\hline Kurtuluş & 2012 & Scientific Process Skills Test & - & 0.78 \\
\hline
\end{tabular}

The pilot study was applied to 216 6th grade students by Kurtuluş (2012) within the formation process of the test which consisted of 36 questions. 12 entries were excluded, regarding the distinctiveness and the difficulty of the questions and a test which consisted of 24 questions was formed at the end of the application. The test's Cronbach alpha credibility 
coefficent was determined as 78. The dispersion of the questions in the SPST according to the skills is given in Table 2 .

Table 2. Dispersion of the questions in the SPST according to the skills

\begin{tabular}{lll}
\hline & Scientific Process Skill & Question \\
\hline & Observation & $2 / 7$ \\
Plan and start & Classification & $3 / 5$ \\
& Guessing & $6 / 9$ \\
& Inference & $14 / 18$ \\
& Producing & $11 / 13$ \\
& Measuring & $1 / 20$ \\
Practice & Forming hypotheses & $16 / 23$ \\
& Designing an experiment & $15 / 19$ \\
& Checking variables & $4 / 12$ \\
& Recording data & $10 / 24$ \\
\hline Analysis and inference & Interpretation of variables & $17 / 21$ \\
\hline
\end{tabular}

Within the scope of this study, the pilot study was made for validity and reliability before the test was used by the researcher. SPST was applied 133 fifth grade students in this pilot study. In the practice, it was observed that the students could complete the test in a course hour and did not have any difficulties. At the end of this pilot study, the Cronbach's alpha credibility coefficient of the SPST was determined as 72 by the researcher. A credibility coefficient over 70 is generally considered as sufficient for the credibility of the test scores for the tests which will be used in choosing and classifying the individuals (Büyüköztürk, 2002).

\subsubsection{Writing to Learn Activities}

The target of this research was the students' doing writing to learn activities in order to study the effect of the use of multimodal representations. These writing activities became an important writing to learn activity for the students to use the multimodal representations, to know them and to be able to practice and transform the modes into each other. These writing activities prepared by the students were evaluated through an evaluation rubric. The evaluation was made from on four basic dimensions. They are the evaluation of the text, the general evaluation of the summary, the general evaluation of the alternative modes and the individual mode analysis. The text's being grammatical, the students' ability to express the concepts expected to be mentioned, their correct use of the concepts, the writing characters' and the writing language's suitability for the level are the criteria in the evaluation part. The presence of the key words which should be found in the summary is also the criteria in the text evaluation part. Using alternative modes together with the text, the alternative modes' relation to each other and the alternative modes' being related to more than one concept were evaluated in the general evaluation of the summary part. Examples given or not given in the writing and the emphasis on the main idea were also evaluated in the general evaluation of the summary part. The sort and the total number of each mode used in the summary, the total number of the inappropriate (unnecessary) modes and the total number of the appropriate modes were indicated in the general evaluation of the alternative modes part. The levels and the qualities of the appropriate modes which were determined in the general evaluation part were tried to be determined in the individual mode analysis part. The total score obtained made the total score of the writing activity.

\section{Results}

\subsection{Scientific Process Skills Pre and Post-test}

It was tried to determine whether there was a statistical difference between the groups with the pre-SPS applied in the beginning of the study. The t-test results for the independent samples indicate that there is not a statistically significant difference between the groups at the $\mathrm{p}<0.05$ level $\left(\mathrm{t}_{(30)}=-0.152, \mathrm{p}=0.881\right)$. The average and the standard deviation of the pre-SPST scores of the groups are given in Table 3.

Table 3. Scientific Process Skills Pretest

\begin{tabular}{lllllll}
\hline & Groups & n & Mean & SD & t & $p$ \\
\hline \multirow{2}{*}{ Pre-SPST } & Control & 17 & 10.647 & 3.30 & -0.152 & 0.881 \\
\cline { 2 - 4 } & Experiment & 15 & 10.866 & 4.67 & & \\
\hline
\end{tabular}

The same test was applied again as the post-test to the students, with the completion of the application stage. Although there was not a statistically significant difference in the scores the students took from the pretest, ANCOVA was applied on the scores of the post-test. The unexplained change (mistake variance) was reduced in the covariance analysis in which the averages controlled the influence of an independent variable compared (Can, 2014). The pretest scores of each group were used as the common variables in the analysis of the data with ANCOVA. The scientific process skills post-test adjusted scores of the students in the experimental group and the control group corrected according to their scientific process pretest scores are given in Table 4. 
Table 4. Scientific Process Skills Posttest

\begin{tabular}{llll}
\hline Groups & $\mathrm{n}$ & Mean & Adjusted mean \\
\hline Control & 17 & 10,294 & 10,34 \\
Experiment & 15 & 18,00 & 17,94 \\
\hline
\end{tabular}

When the Table 4 is analysed, it can be said that there is a difference between the experimental and control groups according to the corrected scientific process skills post-test average scores. The results of ANCOVA made about the significance of this difference are in the table below.

Table 5. ANCOVA result of SPST

\begin{tabular}{lllllll}
\hline Source & Sum of squares & df & Mean squares & F & $\mathrm{p}$ & $\eta_{\mathrm{p}}{ }^{2}$ \\
\hline Pre-SPST & 109.115 & 1 & 109.115 & 5.606 & 0.250 & 0.162 \\
Group & 460.044 & 1 & 460.044 & 23.637 & 0.000 & 0.449 \\
Error & 564.414 & 29 & 19.463 & & \\
Total & 7335.000 & 32 & & & \\
\hline
\end{tabular}

When the data in Table 5 is analysed, the post-test average points of the experimental and control groups corrected controlling their pretest scientific process skill score indicate that there is a difference at a significant level between the experimental and control groups $\left(\mathrm{F}_{(1,30)}=23.637, \mathrm{p}<.05, \eta_{\mathrm{p}}{ }^{2}=0.449\right)$. When the partial eta square value $\left(\eta_{\mathrm{p}}{ }^{2}\right)$ is analysed, it is seen that using multimodal representations in the writing to learn activities explains the $44,9 \%$ of the variability in the post-SPST scores, as something independent from the pre-SPST variable. Using multimodal representations in the writing to learn activities is the difference of the experimental group from the control group. The scientific process skills of the students were influenced as a result of the practices done in the experimental group.

\subsection{Writing to Learn Activity}

The writing activities were actualized as text evaluation, general evaluation of the summary and the general evaluation of the modes used. The evaluations remarked in this part are given under separate headings for each unit.

\subsubsection{U1 writing to Learn Activities}

\section{U1 text evaluation}

The writing's being grammatical, the suitability of the writing characters for the person, suitability of the writing language for the level of the student and the correct use of the rules were considered while the text was being evaluated for the writing activities. The evaluation of the concepts mentioned or not mentioned in the text was considered. The presence of the keywords in the unit in the writing activity was also considered. While the students generally mentioned the concepts of force $(f=32)$, movement $(f=31)$, dynamometer $(f=23)$, force unit $(f=20)$, frictional force $(f=26)$ and contact force / non-contact force $(f=6)$ in the writing activity, they mentioned the concept "contact / non-contact force" $(f=6)$ less than the others. While each student in the experimental group included 5 concepts in the writing activity in average, each student in the control group included 4 concepts in average. When each student in the experimental and the control group was studied separately, it was seen that the students in the experimental group included the concepts "force, movement, dynamometer, force unit, friction force" more in their writing activities. However, they included the concepts "contact force / non-contact force" less in their writing activities. As for the students in the control group, they included the concepts "force, movement, friction force" more but they included the other concepts less in their writing activities.

\section{U1 evaluation of the summary}

The purpose of the writing activity is to enable the students to use the modal representations in a suitable way in the text. Because of this reason, whether the modal representations were used or not used in the writing, the relation between the modal representations used and whether the modal representations were related or not related to more than one concept were the aspects evaluated while the writing activity was being evaluated. Whether the examples were used or not used while doing the writing activity and the emphasis on the main idea were also the aspects evaluated while the writing activity was being evaluated.

While the use of the alternative modes was being evaluated together with the text, the writing activities which consisted of only text were evaluated as 0 (No), the writing activities in which 1 or 2 representation modes were used were evaluated as "partly". The writing activities in which more representation modes were used were evaluated as 2.

When the writing activities of the students were analysed, it was determined that 10 students in the control group did not use modes at all, 6 students used one or two modes and 1 student used three or more modes. A section from the homework of the student who used most modes is given in Figure 1. When the section was analysed, it was seen that the student used a graphic, one of the modes, after the text. In the text, he told that the force moved a book put on the table would be easier than the force applied to move two or three books put on each other and he visualized the text this way. 

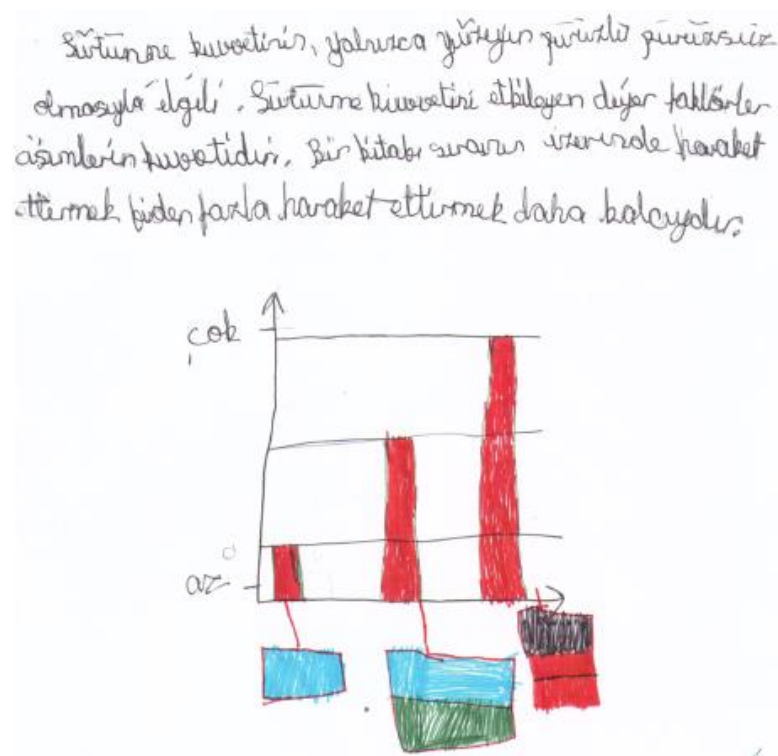

Figure 1. Example from the control group about U1

When the data about the number of the modes used by the students in the experimental group was analysed, no writing activities without any modes used were encountered and it was determined that 1 student used one or two modes and 14 students included 3 or more modes in their writing activities. Almost all of the students in the experimental group used many modes. A section from the home-works of the students is given in Figure 2. When the writing activities are analysed, it can be said that the modes are related to each other and the modes enable the students to emphasize on the details of the subject while doing the writing activity. For example, the student explains the force with his own sentences and exemplifies it from daily life in the section in Figure 2. Moreover, it is seen that he indicates the force as contact force and non-contact force making a classification and he associates the listing mode.

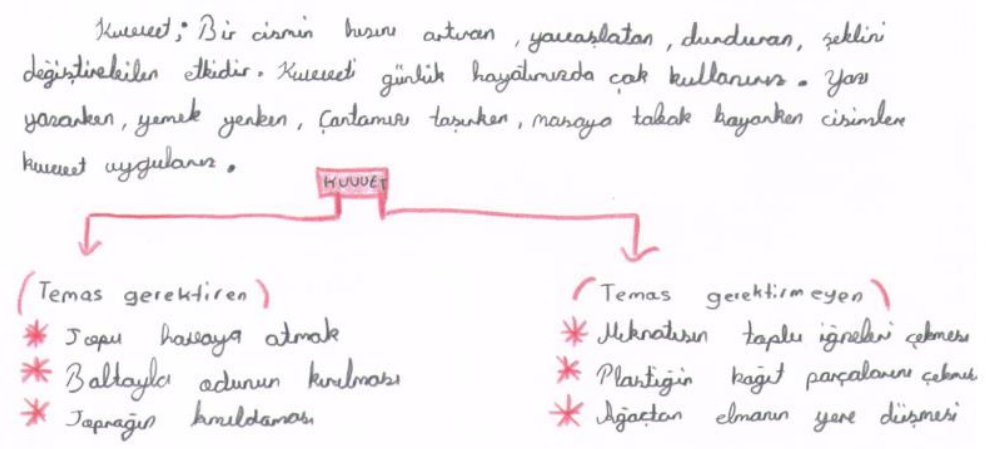

Figure 2. Example from the experimental group about U1

$\mathrm{U} 1$ general evaluation of the alternative modes

When the writing activities were generally evaluated, it was seen that the modal representations used by the students in their writing activities were respectively texts $(f=82)$, pictures $(f=70)$, lists $(f=26)$, graphics $(f=16)$, mathematical expressions $(f=14)$ and table representation mode $(f=9)$. They are given from the most frequent to the least. The findings about the evaluations aimed at the kind of mode used from the point of the groups are given in Graphic 1.

When Graphic 1 was analysed, it was determined that texts $(f=29)$, pictures $(f=24)$, mathematical expressions $(f=6)$, graphics $(f=5)$ and lists $(f=4)$ were the multimodal representations used by the students in the control group in their writing activities. Tables $(f=0)$ were not used at all by them. As for the experimental group, the multimodal representations used by the students in their writing activities were texts $(f=53)$, pictures $(f=46)$, lists $(f=22)$, graphics $(f=11)$, tables $(f=9)$ and mathematical expressions $(f=8)$. Moreover, it was determined that the students in the control group gave more place to the inappropriate / unnecessary modes in their writing activities. 


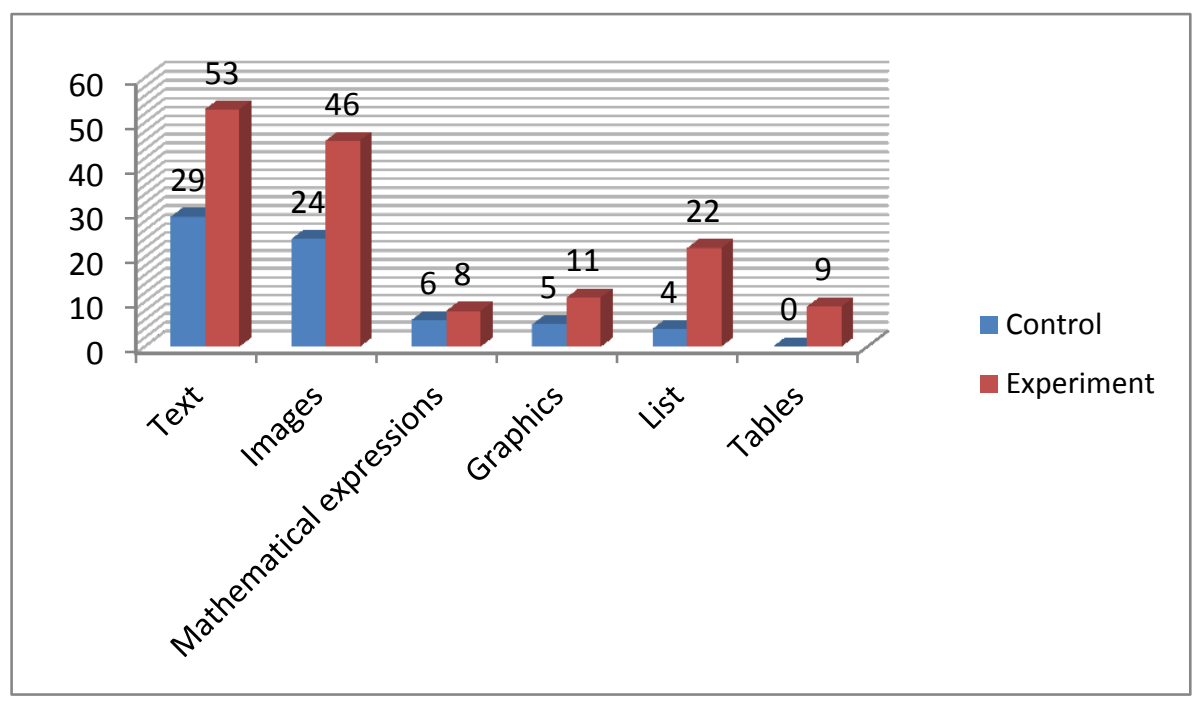

Graphic 1. Alternative modes used for Unit 1

\subsubsection{U2 Writing to Learn Activities}

\section{$\mathrm{U} 2$ text evaluation}

It was seen that the students generally included concepts like "light" $(f=32)$, "sound" ( $f=32)$, "shadow" $(f=9)$, "transparent, semi translucent and opaque matter" $(f=20)$, "lunar and solar eclipse" ( $f=11)$ and "difference between light and sound" ( $f=13)$. In addition, while every student in the experimental group included 4-5 concepts in their writing activities in average, every student in the control group included 2-3 concepts in average. When each student in the experimental and control groups was analysed separately, it was seen that the students in the experimental group included almost all of the concepts "light, sound, transparent, semi translucent and opaque matter, lunar and solar eclipse, difference between light and sound" in their writing activities. As for the students in the control group, while they included the concepts "light and sound" more in their writing activities, they included the other concepts less.

\section{$\mathrm{U} 2$ evaluation of the summary}

When the writing activities of the students were analysed, it was determined that 10 students in the control group used no modes, 6 students used one or two modes, 1 student used three and more modes. A section from the homework of the student who used most modes in the control group is shown in Figure 3. In the section, the student explains that the propagation of the sound can be different in different environments by a text. Moreover, he gave an example for the technological application of the propagation of the sound in water. The student also expresses this example visually using a picture representation mode. In the continuation of the picture mode, he makes an explanation using a text representation mode again.

When the data about the number of the modes used by the students in the experimental group was analysed, no writing activities without modes were seen and it was also determined that 2 students used one or two modes and 13 students included 3 or more modes in their writing activities. Almost all of the students in the experimental group used an exceeding number of modes. When the writing activities are analysed like in U1, it can be said that the modes are related to each other and they enable to emphasize on the details of the subject while doing the writing activity. For example, in the section below, the student in the experimental group explains an observation he made about the change of the shadow length during the day using a text mode (Figure 4). Later, the student presents his data on the observation he did using a table and he supports it with a graphic. 

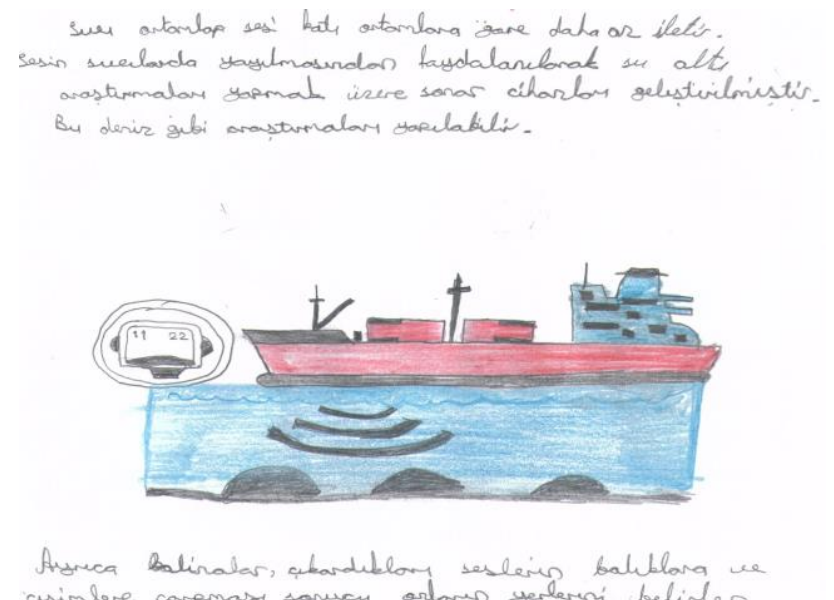

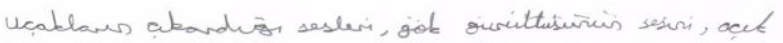

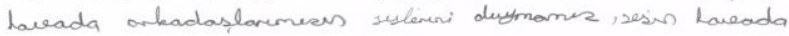

yoyildion Lontlor.

Figure 3. Example from control group about U2

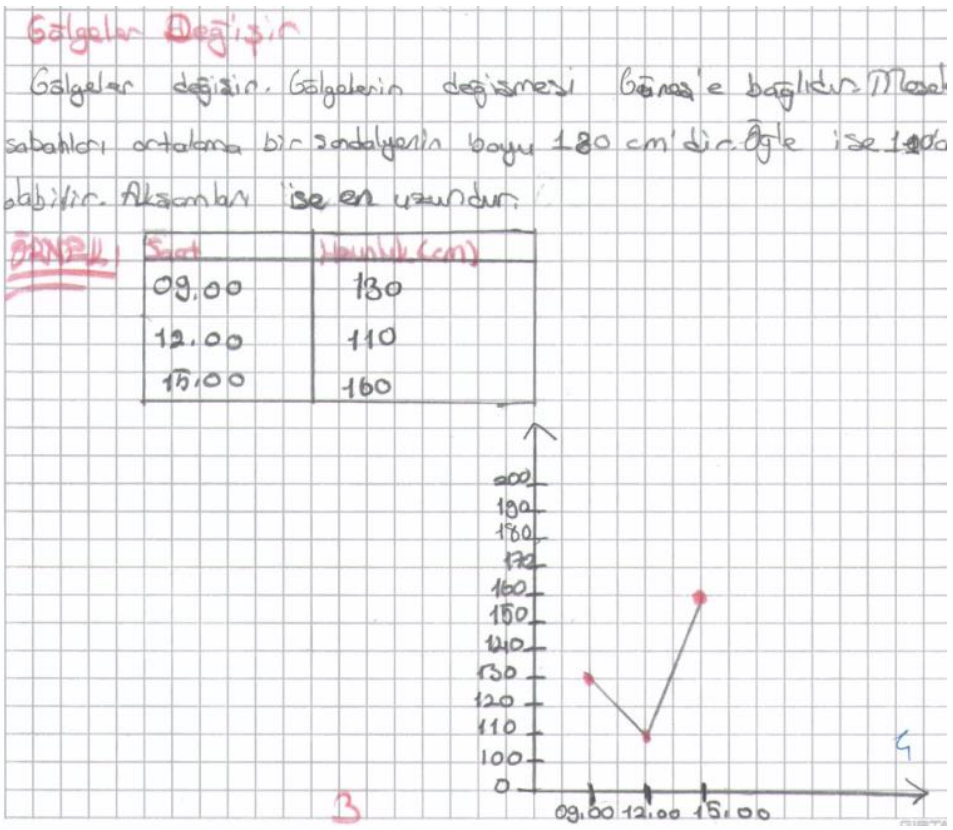

Figure 4. Example from the experimental group about U2

U2 general evaluation of the alternative modes

The representation modes used by the students in their writing activities were respectively determined as texts $(f=122)$, pictures $(f=103)$, lists $(f=18)$, tables $(f=16)$, graphics $(f=13)$ and mathematical expressions $(f=2)$ from the most frequent to the least. Graphic 2 showing the number of the modes from the point of both groups is given below. When Graphic 2 was analysed, it was determined that the modes used by the students in the control group in their writing activities were texts $(f=54)$, pictures $(f=28)$ and lists $(f=4)$ but the mathematical expressions, graphics and tables were not used at all. As for the experimental group, the modes used by the students in their writing activities were determined as pictures $(f=75)$, texts $(f=68)$, tables $(f=16)$, lists $(f=14)$, graphics $(f=13)$ and mathematical expressions $(f=2)$. Similar to U1, it was determined that the students in the control group included the inappropriate / unnecessary modes more in their writing activities. 


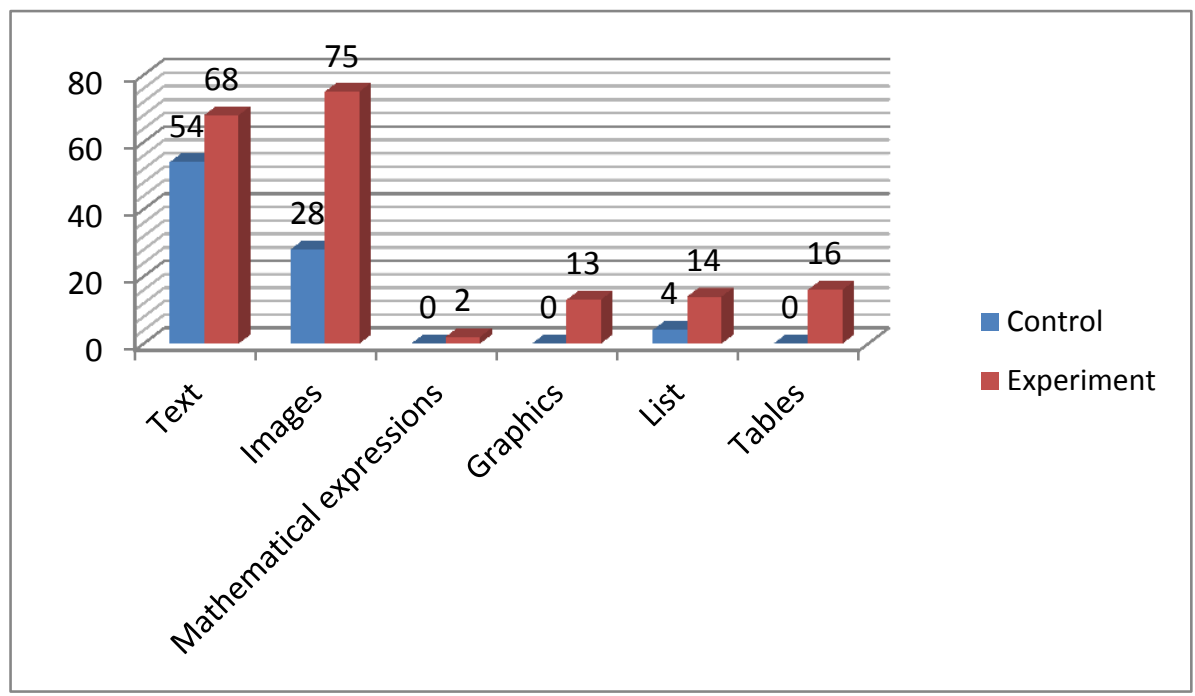

Graphic 2. Alternative modes used for Unit 2

\subsection{Relation between the Writing Activities and SPS}

The Pearson correlation between the writing to learn scores of the students for U1 and U2 and the SPS post-test point were considered. If the correlation coefficient is between 0.700-1.000, it is defined as a relation at high level. If it is between 0.700-0.300, it is defined as a relation at medium level and if it is between 0.300-0.000, it is defined as a relation at low level (Büyüköztürk et al., 2013). The results are given in Table 6.

Table 6. Correlation coefficient between the writing scores for each unit and the SPST score

\begin{tabular}{|c|c|c|c|c|}
\hline & & U1WTS & U2WTS & SPSTS \\
\hline \multirow[t]{3}{*}{ U1WTS } & Pearson Correlation & 1 & & $.739 * *$ \\
\hline & Sig. (2-tailed) & & & .000 \\
\hline & $\mathrm{N}$ & 32 & & 32 \\
\hline \multirow[t]{3}{*}{ U2WTS } & Pearson Correlation & & 1 & $.751 * *$ \\
\hline & Sig. (2-tailed) & & & .000 \\
\hline & $\mathrm{N}$ & & 32 & 32 \\
\hline \multirow[t]{3}{*}{ SPSTS } & Pearson Correlation & $.739 * *$ & $.751 * *$ & 1 \\
\hline & Sig. (2-tailed) & .000 & .000 & \\
\hline & $\mathrm{N}$ & 32 & 32 & 32 \\
\hline
\end{tabular}

$* \mathrm{p}<.05, * * \mathrm{p}<.01$

U1WTS: Unit 1 Writing total Score

U2WTS: Unit 2 Writing total score

SPST: Scientific process skills test score

It is determined that there is a positive and significant correlation at a high level between the U1 writing activity total score and the scientific process skill test score $(r=0.739, \mathrm{p}<.01)$. When the determination coefficient $\left(\mathrm{r}^{2}=0.55\right)$ is considered, it can be said that the $55 \%$ of the total points taken from the SPS post-test originates from the point the students take from the writing activities. A positive and significant correlation at a high level was determined between the $\mathrm{U} 2$ writing activities total score and the scientific process skill test score $(\mathrm{r}=0.751, \mathrm{p}<.01)$. When the determination coefficient $\left(\mathrm{r}^{2}=0.55\right)$ is considered, it can be said that the $56 \%$ of the total score of the BSB post-test originates from the writing activities prepared by the students.

\section{Discussion and Conclusion}

The purpose of this study is to search the impact of using representation modes in writing to learn activities on the scientific process skills of the 5th grade students. As a result of the practices done for this purpose, it was determined that the students in the experimental group differentiated from the control group in their scientific process skills in terms of multimodal representation use in their writing to learn activities. When the findings of the SPS preliminary test were 
analysed, no significant difference was found between the experimental and the control groups. In this respect, it can be said that the scientific process skills of the students in the application and the control groups are similar in the beginning of the study. When the findings of the SPS post-test are analysed, it is observed that there is a significant difference between the groups on behalf of the experimental group in terms of scientific process skills. Using representation modes in writing to learn activities has improved the scientific process skills of the students. The success average of the control group in scientific process skills seems a little decreased when the preliminary and post-tests are compared. When the preliminary and post-tests are compared for the success average of the control group in terms of scientific process skills, a very small decline is seen. When the preliminary and post-tests were compared for the success average of the experimental group in terms of scientific process skills, a vast scale of increase was determined. A positive significant correlation at a high level was found between the SPS scores the students took from their writing activities and it ranks among the findings. While the writing activity 1 explains the $55 \%$ of the SPS scores, the writing activity 2 explains the $56 \%$ of the SPS scores. Thus, it can be claimed that the use of the representation modes in writing to learn activities improves the students' scientific process skills.

Learning strategies where active participation in the learning process is provided and which enable the students to structure the knowledge in their own minds and which are based on research and questioning are targeted to use in science lessons (MNE, 2013). Reaching the knowledge using research ways and methods and the knowledge production skills are described as scientific process skills in science (Tan \& Temiz, 2003). The students' becoming scientifically literate individuals in reaching and producing knowledge and their being familiar with scientific thought at schools are related to their learning the concepts about these thoughts (DeBoer, 2000). It was determined that the students in the experimental group included more concepts in average when compared to the control group in both writing activities within the scope of the study. It is known that the modal representations make learning scientific concepts easier (Ainsworth, 2008). Using modal representations enables the students to indicate the concepts they learn in different ways (Waldrip, Prain \& Carolan, 2006; Blown \& Bryce, 2010), think what they learn and be able to review within a scientific process (Mayer, 2003; Schnotz \& Bannert, 2003). Using modal representations is understood from the use of the modal representations by the students in the experimental group more frequently and variously when compared to the students in the control group in their writings. It is also understood from their use of the modal representations they made by relating them to each other. When it is considered that the modal representation training enables learning scientific thoughts and sharing these thoughts in different formats, their simultaneous actualization in student centered practices like the writing activities can lead an extensive impact on the improvement of the students' perception of modal representations and it can lead an extensive impact also on the improvement of their process skills like reading and writing and conceptual learning (Demirbağ \& Günel, 2014). This situation has been reflected in the scientific process skills of the students.

In conclusion, while the experimental group uses more modes in the writing activity when compared to the control group, using different modes has a more numerically homogeneous structure in the experimental group when compared to the control group. The experimental group's use of more modes and their use of less unnecessary modes indicate that they have interiorised and used them much more consciously. While using multimodal representations in writing activities has been actualized in the experimental group, it can be said that awareness about the modal representations has not formed in the control group. Its reason originates from achieving results on behalf of the experimental group in terms of the frequency of the use of modes and their quality, in other words, their suitability for use in the writing activity. One of the common views about the use of the modes is their dependence on the students' interest and their having an important role for the conditions needed for effective learning (Ainsworth, 1999).

About the multiple modes, it is important for the students to think how they will use the multiple modes and how they can make a justification using the multiple modes about the related subject. As it is remarked in the studies made about the modal representations, it is striking that the students who gain awareness and who practice about the conscious use of the representations learn the scientific concepts deeply (Airey \& Linder, 2008; Kabataş Memiş, 2015) and their linguistic skills such as reading comprehension and writing improve (Demirbağ \& Günel, 2014). In this respect, practices which the students can reflect their need for learning, their limits and interests individually through them contribute to their learning the subject. Practices that can contribute to the scientific literacy in them in an effective way in which they can indicate the verbal, visual and numerical representations as sources also make contributions to their learning (Waldrip et al., 2006). Using multimodal descriptions in writing to learn activities enables the students to learn and it has a potential for affecting their scientific process skills. It is one of the important results of this study. The students' thinking about using which mode where and their contacting the modal descriptions are the results of their planning when writing. Thus, the students' planning when writing (Klein, 1999) and their using multimodal representations can indicate that they have passed through a scientific process. Because of these reasons, teachers should guide the students in using the modes and they should offer them the learning environments they may need. 


\section{References}

Ainsworth, G. C. (2008). Ainsworth \& Bisby's dictionary of the fungi. Cabi.

Ainsworth, S. (1999). The functions of multiple representations. Computers \& Education, 33(2), 131-152. https://doi.org/10.1016/S0360-1315(99)00029-9

Ainsworth, S. (2006). DeFT: A conceptual framework for considering learning with multiple representations. Learning and instruction, 16(3), 183-198. https://doi.org/10.1016/j.learninstruc.2006.03.001

Airey, J., \& Linder, C. (2008). A disciplinary discourse perspective on university science learning: Achieving fluency in a critical constellation of modes. Journal of Research in Science Teaching, 46(1), 27-49. https://doi.org/10.1002/tea.20265

Aslan, S., \& Tekin, N. (2015). Reporting Laboratory Applications in Argument-Based Science Inquiry Report Format Effects on Conceptual Understanding and Using Modal Representation. Journal of Education Faculty, 17(1). https://doi.org/10.17556/jef.08506

Atila, E., Günel, M., \& Büyükkasap, E. (2009). Investigating the effect of using multimodal representations within wiriting-to-learn approach on middle school science achievement. ESERA (European Science Education Research Association) conference, İstanbul, Turkey.

Balgopal, M. M., Wallace, A. M., \& Dahlberg, S. (2012). Writing to learn ecology: A study of three populations of college students. Environmental Education Research, 18(1), 67-90. https://doi.org/10.1080/13504622.2011.576316

Blown, E., \& Bryce, T. G. (2010). Conceptual coherence revealed in multi-modal representations of astronomy knowledge. International Journal of Science Education, 32(1), 31-67. https://doi.org/10.1080/09500690902974207

Büyüköztürk, Ş. (2002). Handbook of data analysis for social sciences. Ankara: Pegem-A Publishing.

Büyüköztürk, Ş., Çakmak, E. K., Akgün, Ö. E., Karadeniz, Ş., \& Demirel, F., (2013). Scientific research methods. Ankara: Pegem-A Publishing.

Can, A. (2014). SPSS Ile Bilimsel Arastirma Sürecinde Nicel Veri Analizi. 2. Baskı. Ankara: Pegem A Publishing.

Çepni, S. (2012). Araştırma ve proje çalışmalarına giriş. 6. Baskı, Trabzon: Celepler Matbaacılık.

Çepni, S., Ayas, A., Johnson, D., \& Turgut, M. F. (1997). Physics teaching. YÖK/Dünya Bankası MEGP, Hizmet Öncesi Öğretmen Eğitimi Publishing, Bilkent, Ankara.

DeBoer, G. E. (2000). Scientific literacy: Another look at its historical and contemporary meanings and its relationship to science education reform. Journal of research in science teaching, 37(6), 582-601. https://doi.org/10.1002/1098-2736(200008)37:6<582::AID-TEA5>3.0.CO;2-L

Demirbag, M., \& Gunel, M. (2014). Integrating argument-based science inquiry with modal representations: Impact on science achievement, argumentation, and writing skills. Educational Sciences: Theory \& Practice, 14(1), 386-391. https://doi.org/10.12738/estp.2014.1.1632

Elo, S., \& Kyngäs, H. (2008). The qualitative content analysis process. Journal of advanced nursing, 62(1), 107-115. https://doi.org/10.1111/j.1365-2648.2007.04569.x

Galbraith, D., \& Rijlaarsdam, G. (1999). Effective strategies for the teaching and learning of writing. Learning and instruction, 9(2), 93-108. https://doi.org/10.1016/S0959-4752(98)00039-5

Glynn, S. M., \& Muth, K. D. (1994). Reading and writing to learn science: Achieving scientific literacy. Journal of research in science teaching, 31(9), 1057-1073. https://doi.org/10.1002/tea.3660310915

Günel, M., Atila, M. E., \& Büyükkasap, E. (2009). The Impact of Using Multi Modal Representations within Writing to Learn Activities on Learning Electricitty Unit at $6^{\text {th }}$ Grade. Elementary Education Online, 8(1), 183-199.

Hand, B., \& Prain, V. (1996). Writing for Learning in Science: A Model for Use within Classrooms. Australian Science Teachers Journal, 42(3), 23-27.

Hand, B., \& Prain, V. (2002). Teachers implementing writing-to-learn strategies in junior secondary science: A case study. Science Education, 86(6), 737-755. https://doi.org/10.1002/sce.10016

Hand, B., Hohenshell, L., \& Prain, V. (2004). Exploring students' responses to conceptual questions when engaged with planned writing experiences: A study with year 10 science students. Journal of Research in Science Teaching, 41(2), 186-210. https://doi.org/10.1002/tea.10128

Hand, B., Lawrence, C., \& Yore, L. D. (1999). A writing in science framework designed to enhance science literacy. International journal of science education, 21(10), 1021-1035. https://doi.org/10.1080/095006999290165 
Kabataş, M. E. (2015). The effect of Using Multi Modal Representation on Learning "force and Motion" Unit of students at $7^{\text {th }}$ Grade. Çukurova University Faculty of Education Journal, 44(1).

Klein, P. D. (1999). Reopening inquiry into cognitive processes in writing-to-learn. Educational psychology review, 11(3), 203-270. https://doi.org/10.1023/A:1021913217147

Klein, P. D. (2000). Elementary students' strategies for writing-to-learn in science. Cognition and Instruction, 18(3), 317-348. https://doi.org/10.1207/S1532690XCI1803_2

Kurtuluş, N. (2012). The Effect of Instructional Applications Based on Creative Thinking on Scientific Creativity, Scientific Process Skills and Academic Achievement. Master Thesis, Karadeniz Teknik University, Institute of educational Sciences. Trabzon.

Kurtuluş, N., \& Yiğit, N. (2010). A study of Development of Scientific Process Skill Test, $9^{\text {th }}$ Annual Meeting of National Science and Mathematics Education Conference (UFBMEK), Dokuz Eylül University, 23-25 September, İzmir.

Mayer, R. E. (2003). The promise of multimedia learning: using the same instructional design methods across different media. Learning and instruction, 13(2), 125-139. https://doi.org/10.1016/S0959-4752(02)00016-6

Ministry of National Education (2013). Science Lesson (6th, 7th, and 8th grades) Education Program, Ankara, Turkey.

Prain, V., \& Hand, B. (1999). Students' perceptions of writing for learning in secondary school science. Science Education, 83(2), 151-162. https://doi.org/10.1002/(SICI)1098-237X(199903)83:2<151::AID-SCE4>3.0.CO;2-S

Prain, V., \& Waldrip, B. (2006). An exploratory study of teachers' and students' use of multi-modal representations of concepts in primary science. International Journal of Science Education, 28(15), 1843-1866. https://doi.org/10.1080/09500690600718294

Sampson, V., \& Walker, J. P. (2012). Argument-driven inquiry as a way to help undergraduate students write to learn by learning to write in chemistry. International Journal of Science Education, 34(10), 1443-1485. https://doi.org/10.1080/09500693.2012.667581

Schnotz, W., \& Bannert, M. (2003). Construction and interference in learning from multiple representation. Learning and instruction, 13(2), 141-156. https://doi.org/10.1016/S0959-4752(02)00017-8

Stemler, S. (2001). An overview of content analysis. Practical assessment, research \& evaluation, 7(17), 137-146.

Tahir, T. A. Ğ. A., \& Süleyman, Ü. N. L. Ü. (2013). Yazma eğitiminde karşılaşılan sorunlar üzerine bir inceleme.

Tan, M., \& Temiz, B. K. (2003). The Importance and Role of the Science Process Skills in Science Teaching. Pamukkale University Journal of Education, 13(13), 89-101.

Temiz, B. K., \& Tan, M. (2009). Assessing the graph Drawing Abilities with a Check List. SelçukUniversity Journal of Ahmet Keleşoğlu Education Faculty, 27, 71-83.

Tolppanen, S., Rantaniitty, T., McDermott, M., Aksela, M., \& Hand, B. (2013). Effectiveness of a Lesson on Multimodal Writing in Science Education. LUMAT, 1(5), 503-522.

Waldrip, B., Prain, V., \& Carolan, J. (2006). Learning junior secondary science through multi-modal representations. Electronic Journal of Science Education, 11(1).

Yore, L. D. (2000) Enhancing science literacy for all students with embedded reading instruction and writing-to-learn activities. Journal of Deaf Studies and Deaf Education, 5, 105-122. https://doi.org/10.1093/deafed/5.1.105

\section{Copyrights}

Copyright for this article is retained by the author(s), with first publication rights granted to the journal.

This is an open-access article distributed under the terms and conditions of the Creative Commons Attribution license which permits unrestricted use, distribution, and reproduction in any medium, provided the original work is properly cited. 